\title{
Assessment of Physico-chemical Characteristics of Soil collected from Various Locations of Chitrakoot Region, District Satna, Madhya Pradesh
}

\begin{abstract}
Arvind Prasad Dwived
Lecturer, Department of chemistry, Govt. Sanjya Gandhi Smrati Auto P.G.College Sidhi M.P.,India.

Abstract: Chitrakoot is a town and a nagar panchayat in Satna district in the state of Madhya Pradesh, India. Geographical information of Chitrakoot district Satna in located at $24^{\circ} 48^{\prime}$ to $25^{\circ} 12^{\prime} \mathrm{N}$, and longitude at $80^{\circ} 58^{\prime}$ to $81^{\circ} 34^{\prime}$ 'E distance covered by district from east to west is $62 \mathrm{~km}$ and north to south is $57.5 \mathrm{~km}$. Various soil quality parameters were analyzed by using standard procedures. Fifteen Soil sample were collected from two different areas of Chitrakoot region. The temperature-26.0 to $30.0{ }^{\circ} \mathrm{C}, \mathrm{pH} 6.6$ to 8.3, Moisture-1.05 to $3.28 \%$, $\mathrm{N}$ 4.30 to $32.09 \mathrm{mg} / \mathrm{kg}, P-0.22$ to $2.96 \mathrm{mg} / \mathrm{kg}$ and $K-28$ to $57 \mathrm{mg} / \mathrm{kg}$, all the result of all the parameters were below the SQGL recommended level.
\end{abstract}

Keywords: Physico-chemical Parameters, Soil, Chitrakoot region, Satna Distract

\section{INTRODUCTION}

One of the most serious threats faced today by mankind is the pollution of our environment. In fact, most of the developed countries have already realized that the very existence of life on the earth may be endangered if suitable steps are not taken for the control and abatement of air, soil and water pollution ${ }^{[1] .}$ Environmental pollution is one of the most serious problems facing humanity and other life forms on our planet today. Industrial effluents discharged into water bodies contain toxic chemicals, hazardous compounds like phenols, aldehydes, ketones, amines, cyanides, metallic wastes, plasticizers, toxic acids, corrosive alkalis, oils, greases, dyes, biocides, suspended solids, radioactive wastes and thermal pollutants from various industries ${ }^{[2]}$ The contamination concentration in soil depends on the adsorption properties of soil matter its properties determined by organic matter. Variation of organic matter may be the predominant cause of variation in environment concentration in soil. ${ }^{[3]}$ Most of the farmers are using excessive chemical fertilizers and the too much dose of such fertilizers in few soils has rendered high values of $\mathrm{P}$ and $\mathrm{K}$. The retention of $\mathrm{K}$ could also be due the clay minerals formed by chemical weathering of basalts which is the parent material for the soil

${ }^{[4]}$.Soil formation is a constructive as well as destructive process. Destructive process predominates the physical and chemical breaking down of materials, plants and animal structures, which result in the partial loss of more soluble and volatile products. Constructive forces develop new chemical compounds, both mineral and organic that provides new distribution or association characteristics, structural properties as well as chemical compositions. These factors influence the plant growth in the soil $^{[5]}$.

Chitrakoot is a town and a nagar panchayat in Satna district in the state of Madhya Pradesh, India. Geographical information of Chitrakoot district Satna in located at $24^{0} 48^{\prime}$ to $25^{\circ} 12^{\prime} \mathrm{N}$, and longitude at $80^{\circ} 58^{\prime}$ to $81^{\circ} 34^{\prime} \mathrm{E}$ distance covered by district from east to west is $62 \mathrm{~km}$ and north to south is 57.5 $\mathrm{km}$. The town lies in the historical Chitrakoot region; it attracts crowds throughout the year including above occasions and for Free Eye Hospital Camps. Noted 'Ayurvedic' and 'Yoga' centres like 'Arogyadham' are located in Chitrakoot. Chitrakoot means the 'Hill of many wonders'. Chitrakoot falls in the northern Vindhya Range of mountains spread over the states of Uttar Pradesh and Madhya Pradesh. The Chitrakoot region is included in the District Chitrakoot of Uttar Pradesh and the District Satna of Madhya Pradesh. Chitrakoot Parvat Mala includes Kamad Giri, Hanumaan Dhara, Janki Kund, Lakshman pahari, and Devangana famous Religious Mountains. 


\section{Material AND Methods}

\subsection{Sample Collection}

The N, P, K, analysis of soil during month of March 2015. The sampling stations were chosen at different site of the study area. For testing the soil sample were collected in different sterile plastic container cans from each station. After collection of the sample the containers were tightly capped and were immediately transported to the laboratory to avoid any unpredictable changes in the physiochemical characteristics. Sample should be collected in clean and dry containers, and container should be rinsed thoroughly before collection of sample. Stopper the container after collections of the sample. Temperature, $\mathrm{pH}$, Moisture Contents, $\mathrm{N}, \mathrm{P}$ and $\mathrm{K}$ were analyzed in the soil samples during the sampling periods. Various soil quality parameters were analyzed by using standard procedures ${ }^{[6}$, 7].

Table1. List of sampling locations

\begin{tabular}{|l|l|r|l|l|}
\hline S. No. & Sampling Location & Sampling code & Sampling Area & Depth in cm. \\
\hline 1 & M.G.C.G.V Chitrakoot & $\left(\mathrm{SR}_{1}\right)$ & Residential area & $12 \mathrm{~cm}$ \\
\hline 2 & Nears of Primary school & $\left(\mathrm{SR}_{2}\right)$ & Residential area & $12 \mathrm{~cm}$ \\
\hline 3 & Right side of Kamtanath Mandir & $\left(\mathrm{SR}_{3}\right)$ & Residential area & $12 \mathrm{~cm}$ \\
\hline 4 & In front of Branch Post office & $\left(\mathrm{SR}_{4}\right)$ & Residential area & $12 \mathrm{~cm}$ \\
\hline 5 & Near Primary School & $\left(\mathrm{SR}_{5}\right)$ & Residential area & $12 \mathrm{~cm}$ \\
\hline 6 & KarwiRood Hanumadhara & $\left(\mathrm{SR}_{6}\right)$ & Residential area & $12 \mathrm{~cm}$ \\
\hline 7 & Near DRI Arogyadham & $\left(\mathrm{SR}_{7}\right)$ & Residential area & $12 \mathrm{~cm}$ \\
\hline 8 & Near Tourist Bungalow Ramghat chitrakoot & $\left(\mathrm{SC}_{2}\right)$ & Crop area & $12 \mathrm{~cm}$ \\
\hline 9 & Rajoula farm chitrakoot & $\left(\mathrm{SC}_{3}\right)$ & Crop area & $25 \mathrm{~cm}$ \\
\hline 10 & Ramnathashramshala & $\left(\mathrm{SC}_{4}\right)$ & Crop area & $25 \mathrm{~cm}$ \\
\hline 11 & 1.5Km before in ramghat road & $\left(\mathrm{SC}_{5}\right)$ & Crop area & $12 \mathrm{~cm}$ \\
\hline 12 & Infrant of satna bus stand & $\left(\mathrm{SC}_{6}\right)$ & Crop area & $12 \mathrm{~cm}$ \\
\hline 13 & Nagar panchayat Bariyar & $\left(\mathrm{SC}_{7}\right)$ & Crop area & $12 \mathrm{~cm}$ \\
\hline 14 & Near Brahmadev mandir & \multicolumn{2}{|l}{} \\
\hline
\end{tabular}

\section{RESULT AND DISCUSSION}

In the present study fifteen soil samples were collected from Chitrakoot region of Satna district. Various sampling station are chosen in study area like Rajoula farm, Rajoula, M.G.C.G.V., Kamtanath Mandir, Hanumadhara, Pilikothi, etc. All the parameters are characterize and interpreted. Soil samples were analyzed some physic-chemical parameter like $\mathrm{pH}$, Temperature, Moisture Contents, N, P, K. Soil Samples were collected from two area located crop land and residential in part of the chitrakoot region. Parameters were mean, S.D., and C.V., values shown in Tabel-2 and figure 1-6.

\subsection{Temperature}

The Temperature is basically an important factor for its effect on chemical and biological reaction in soil. Minimum $26{ }^{\circ} \mathrm{C}$ and maximum $30{ }^{\circ} \mathrm{C}$ temperature were found in the crop land soil samples of Chitrakoot region. Temperature results of the all samples are given in table-2 and shown in fig .1. (Tripathi et al. 2014) ${ }^{[8]}$ Studies of Physico chemical characteristics of soil in Shahdol District of Vindhya platue and reported the temperature was observed to be $28.64{ }^{\circ} \mathrm{C}$ to $42.28{ }^{\circ} \mathrm{C}$.

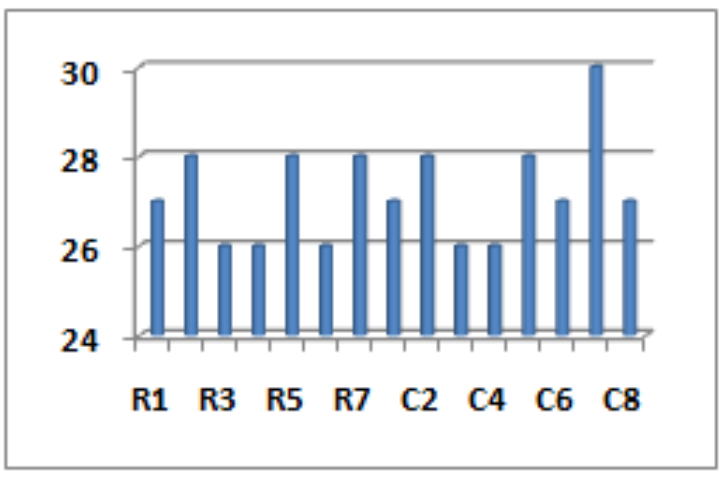

Fig1. Graphical representation of the temperature 


\section{2.pH}

The $\mathrm{pH}$ of the soil taken from the depth of $15 \mathrm{~cm}$ at different sites ranged from 7.2 to 9.0 which indicate that the soil is alkaline. Pandeeswari, N. et al, 2012, ${ }^{[9]}$ reported ranges of $\mathrm{pH}$ of soil were $5-8$. Soil $\mathrm{pH}$ is an important consideration for farmers and gardeners for several reasons, including the fact that many plants and soil life forms prefer either alkaline or acidic conditions or the $\mathrm{pH}$ can affect the availability of nutrients in the soil.

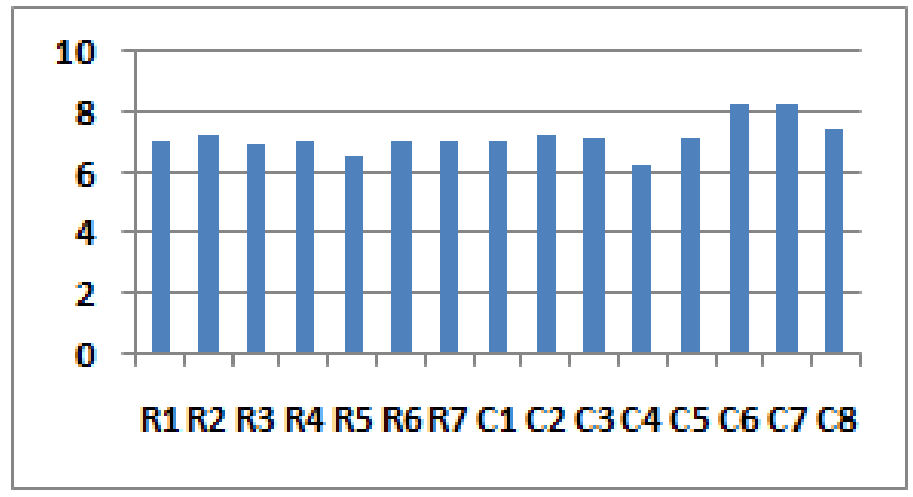

Fig2. Graphical representation of the $\mathrm{pH}$

\subsection{Nitrogen}

Nitrogen contents in Soil of Chitrakoot region were analysed and reported. Its concentration ranged between 4.30 to $32.09 \mathrm{mg} / \mathrm{kg}$. Nitrogen is the most important fertilizer element. Plants respond quickly to application of nitrogen salts. This element encourages above ground vegetative growth and gives a deep green color to the leaves. Plant roots take up nitrogen in the form of $\mathrm{NO}_{3}$ and $\mathrm{NH}_{4}$. The sample station $\mathrm{R}_{3}$ (Kamta H.S.school chitrakoot) Showed maximum nitrogen concentration 32.09 $\mathrm{mg} / \mathrm{kg}$ and Sample station $\mathrm{R}_{7}$ (Arogyadham DRI) showed minimum concentration of nitrogen 4.30 $\mathrm{mg} / \mathrm{kg}$ are shown in table-2. Indra Prasad Tripathi, et al, (2013) ${ }^{[10]}$ Studies characterization of diffuse chemical pollution in Satna District and reported the Nitrogen content varied from 5.17 to 43.59 $\mathrm{mg} / \mathrm{kg}$. (Tripathi et al. 2014) ${ }^{[11]}$ Studied concentration of $\mathrm{Cr}, \mathrm{Pb}, \mathrm{Cd}, \mathrm{Ni}, \mathrm{Cu}$ and $\mathrm{Fe}$ in soil of Umaria District, Vindhya Platue, India and reported N, are found to be 8.86 to $41.50 \mathrm{mg} / \mathrm{kg}$,

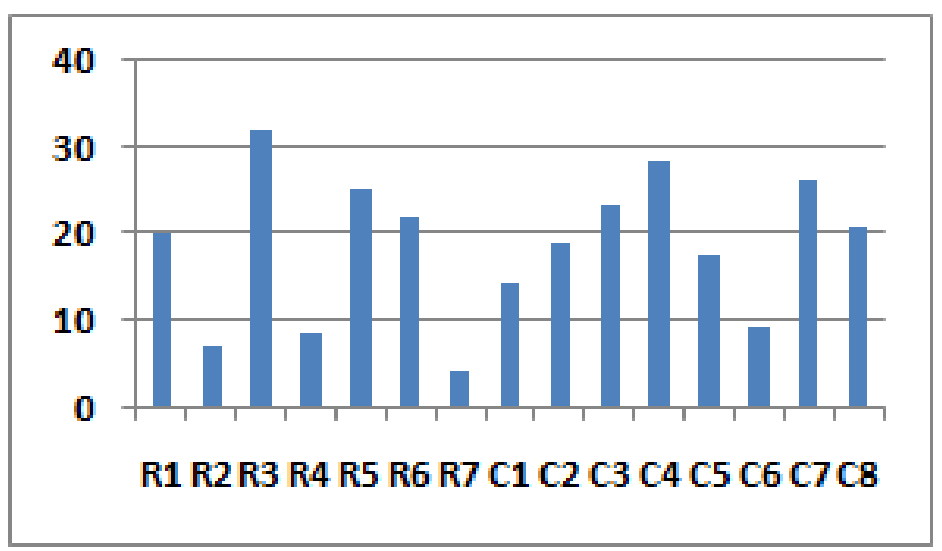

Fig3. Graphical representation of the Nitrogen

\subsection{Phosphorus}

Phosphorus is a part of every living cell in crop. The every activity of plant such as growth, respiration and reproduction depends upon phosphorus levels of the soil in which the crop growth. Jain Parul et al, (2014), ${ }^{[12]}$ suggested phosphorus (P) is necessary for maintaining a balance between the other plant nutrients and ensuring the normal growth of the crop. In the present study the amount of available phosphorus at $\mathrm{C}_{1}$ (Near Brahmadevmandir Mokamgar) $2.96 \mathrm{mg} / \mathrm{kg}$, whereas at $\mathrm{C}_{8}$ (Jankikund hospital chitrakoot) the phosphorus content is very less amount i.e. $0.22 \mathrm{mg} / \mathrm{kg}$. Sahoo et $a l, 2010^{[13]}$ carried out characterization classification and evaluation of soil of Longol Hill, Manipur for rationalland use planning and found phosphorus concentration 0.41 to $2.89 \mathrm{mg} / \mathrm{kg}$. 


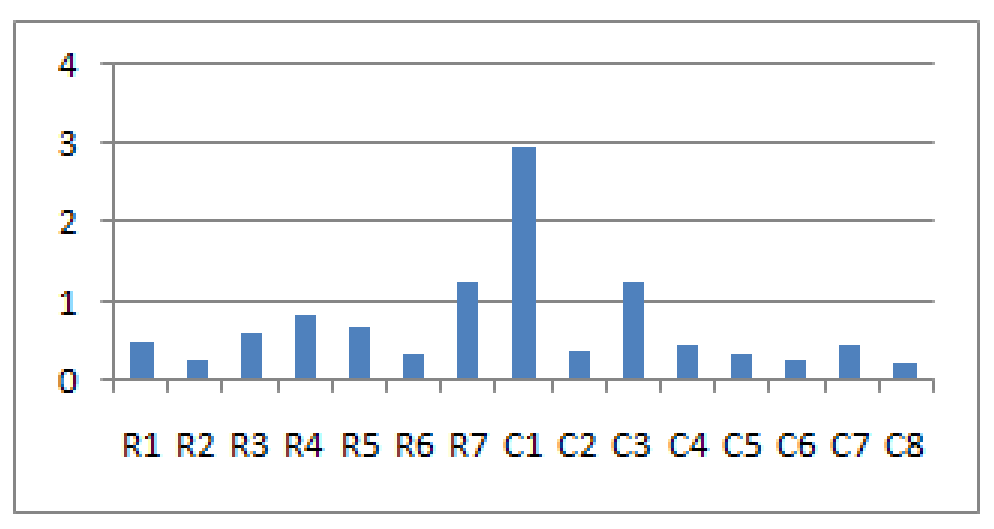

Fig4. Graphical representation of the Phosphorus

\subsection{Potassium}

The Potassium values were ranging between $\mathrm{C}_{8} 28 \mathrm{mg} / \mathrm{kg}$ to $\mathrm{C}_{5} 57 \mathrm{mg} / \mathrm{kg}$. Maximum concentration of Potassium $57 \mathrm{mg} / \mathrm{kg}$ was observed at sampling stations $\mathrm{C}_{5}$ (Satna bus stand). Dwivedi A.P., et al, 2013, ${ }^{[14]}$. carried out assessment of soil and ground water quality in rewa District of Vindhya platue and reported the potassium content ranged from 2.10 to $55.0 \mathrm{mg} / \mathrm{kg}$ Potassium is not an integral part of any major plant component but it plays $\mathrm{s}$ key role in a vast array of physiological process vital to plant growth from protein synthesis to maintenance of plant-water balance ${ }^{[15]}$. All the values of $\mathrm{N}, \mathrm{P}$, and $\mathrm{K}$, were below the recommended level of SQGL Value ${ }^{[16]}$.

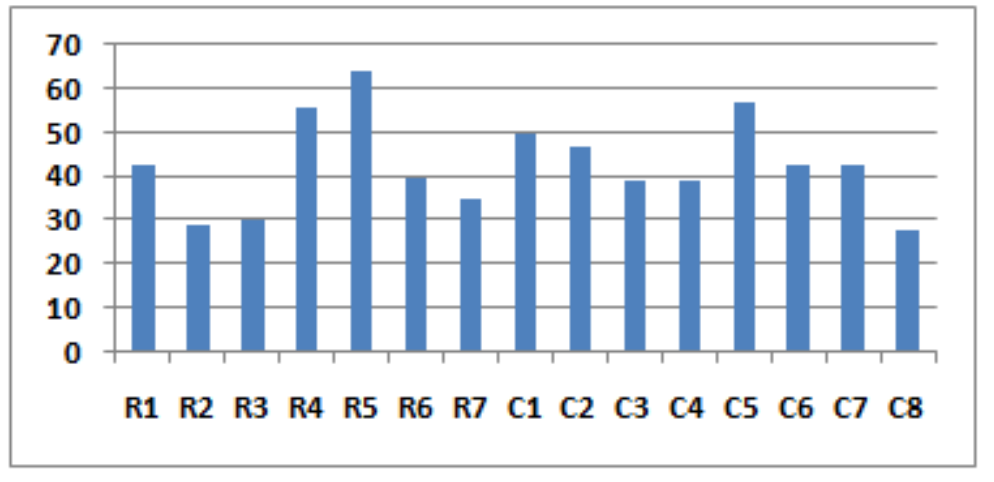

Fig5. Graphical representation of the Potassium

\subsection{Moisture Content}

Moisture content of samples was found 1.05 to $3.28 \%$. In Chitrakoot region we have analyzed minimum moisture content in sample $R_{5}$ (Nayagaonthana) (1.05) and maximum value found in sample $\mathrm{R}_{4}$ (Pilicothichitrakoot) (3.28). N.S. Sonawane, et al ${ }^{[76]}$ Studied Soil Quality Assessment and Heavy Metal Contamination in Agricultural Soil in and around Toranmal (Triable Region) of Maharashta reported the moisture content 3.0 to 4.15. Moisture contents results of the all samples are given in table- 2 and shown in fig. 6.

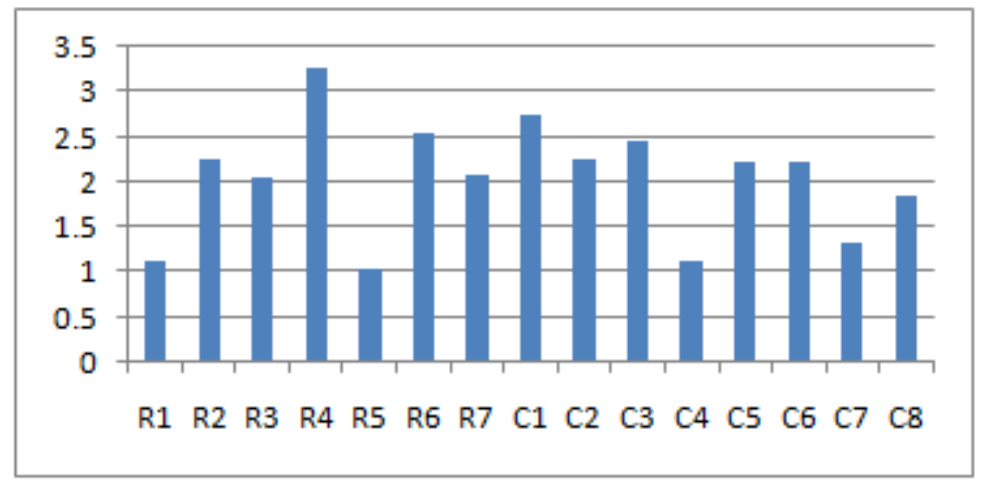

Fig6. Graphical representation of the moisture content 
Assessment of Physico-chemical Characteristics of Soil collected from Various Locations of Chitrakoot Region, District Satna, Madhya Pradesh

Table2. Physico-chemical characteristic of soil collected from different areas of Banda City

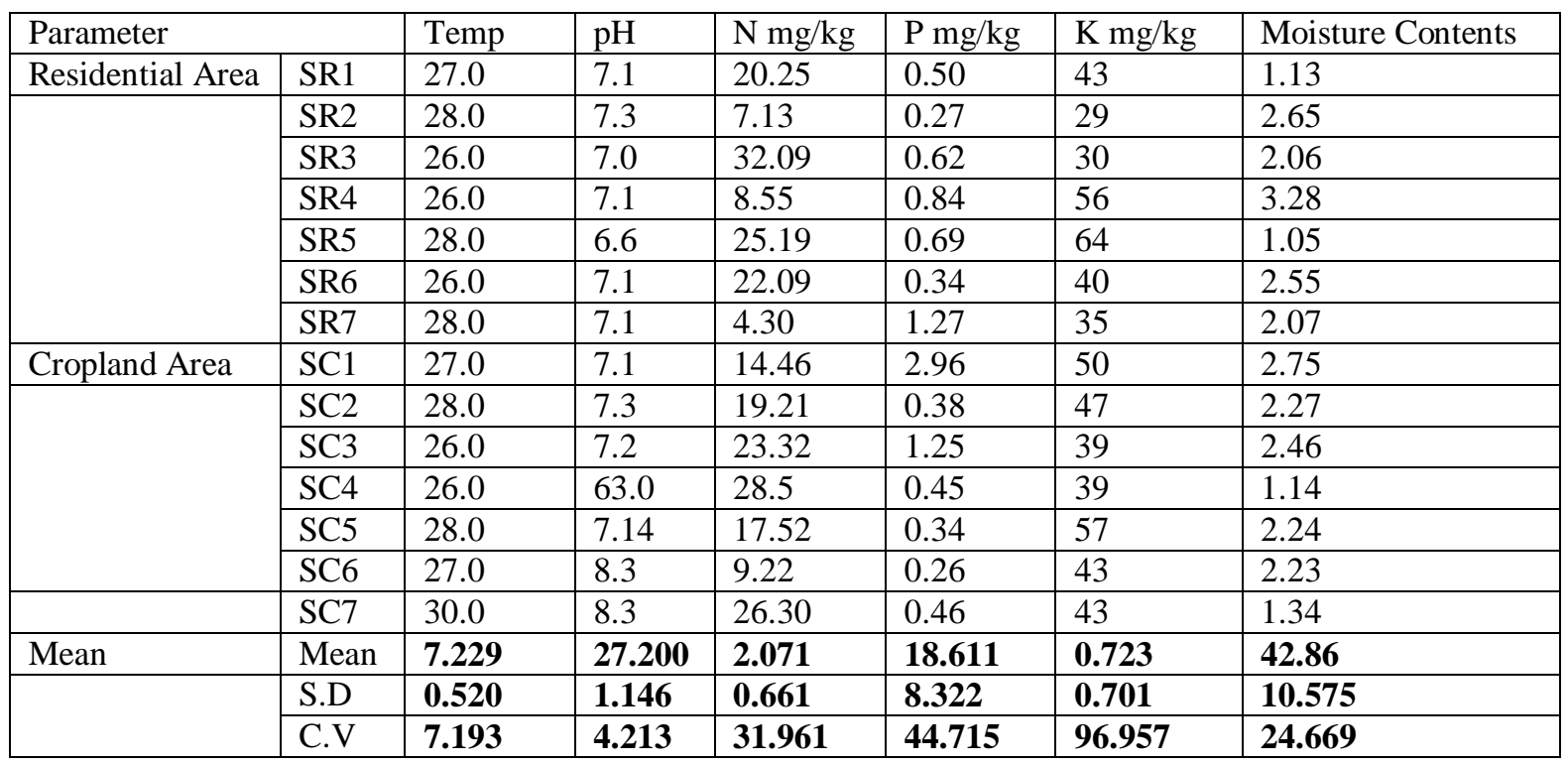

\section{Conclusions}

The study of Various Physico-chemical Parameters, Temperature, $\mathrm{pH}$ Moisture Content, N, P, and K were carried out by using various standard methods reported in the literature. Fifteen Soil sample were collected from two different areas of Chitrakoot region. The temperature-26.0 to30.0 ${ }^{\circ} \mathrm{C}, \mathrm{pH} 6.6$ to 8.3 , Moisture-1.05 to $3.28 \%, \mathrm{~N}-4.30$ to $32.09 \mathrm{mg} / \mathrm{kg}, \mathrm{P}-0.22$ to $2.96 \mathrm{mg} / \mathrm{kg}$ and K-28 to $57 \mathrm{mg} / \mathrm{kg}$ ,all the result of all the parameters were below the SQGL recommended level. It is concluded that the soil of chitrakoot region are not contaminated. Farmer arranges the amount fertilizers and nutrients needed to soil for increase the crop production.

\section{ACKNOWLEDGMENT}

Author would like to thank the University Grant Commission, New Delhi for the financial Support. The author is grateful to Director, National Environmental Engineering Research Institute (NEERI) Nagpur for proving the Instrumental facilities.

\section{REFERENCES}

[1] N. Raman and D. Sathiyanarayn, Physico-chemical Characterization of Soil and Influence of Cation Exchange Capacity of Soil in and Around Chennai, Rasayan J. Chem., 2 (4), 875-885 (2009)

[2] Suraj P.Gajbhiye, S.A. Bhalerao, A Study of Physic-chemical and some Heavy Metal Pollutants in Soil from the Industrial Area of Thane- Belapur MIDC Region, Maharashtra State, India, Research Journal of Chemical and Environmental sciences, 4(1), 43-52 (2016)

[3] A.P. Dwivedi, I.P. Tripathi and M. Suresh Kumar, Assessment of Soil and Ground Water Quality in Rewa District of Vindhya Plateau (India), Journal Environment Sciences and Engs, 5 (1) , 51-54 (2013)

[4] G.S. Wagh , Physico-chemical Analysis of Soil from Eastern Part of Pune City. Universal Journal of Environmental Research and Technology, 3 (1), 93-99 (2013)

[5] K.G. Pujar,, S.C. Hiremath, A.S., Pujar ,U.S. Pujeriand, M.S. Yadawe, Analysis of PhysicoChemical and Heavy Metal Concentration in Soil of Bijapur Taluka, Karnataka. Sci. Revs. Chem. Commun., 2(1), 76-79 (2012),

[6] C. S. Piper A Laboratory Manual of Methods for the Examination of Soil and Determination of the Inorganic Consitate of Plant original edition 1942.Printed in India. Scientific Publisher Jodhpur (Raj.) India.

[7] American public health Association Standard Method for the Examination of Water and Waste water $19^{\text {th }}$ E.d APHA Washington D.C1995.

[8] Indra Prasad Tripathi, Arvind Prasad Dwivedi, M. Suresh Kumar, Physico-Chemical Characteristic of Soil in Shahdol District of Vindhya Platue, Journal of Applicable Chemistry, 3 (3), 1155-1164 (2014) 
[9] N. Pandeeswari, and S. Kalaiarasu, Studies On The Physico-Chemical Properties of The Soil Samples Collected From Different Locations of Tsunami Affected Soils Of Cuddalore District Of Tamil Nadu. Int. J. Current Res. 4(7), 143-145 (2012)

[10] Indra Prasad Tripathi, M. Suresh Kumar and Arvind Prasad Dwivedi, Characterization of Diffuse Chemical pollution in Satna District of Vindhya Region, India, International Research Journal of Environment Sciences, 2(11), 46-60 (2013).

[11] Indra Prasad Tripathi, M. Suresh Kumar and Arvind Prasad Dwivedi, Concentration of Cr, Cd, $\mathrm{Ni}, \mathrm{Cu}$ and $\mathrm{Fe}$ in Soil of Umaria District, Vindhya Platue, India, International Journal of research Analysis and Evaluation, 5(52), 28- 32 (2014)

[12] Jain Parul and Singh Dharmendra, Analysis the Physic-chemical and Microbial Diversity of Different Variety of Soil Collected from Madhya Pradesh India. Scholar Journal of Agricultural Science, 4 (2), 103-108 (2014).

[13] A.K., Sahoo Dipak Sarkar, U. Baruah and P.S. Buttle, Characterization Classification and Evaluation of Soil of Longol Hill, Manipur for Rationall and use Planning. Journal of Indian Society of Soil Science, 54, 355-362(2010).

[14] A.P. Dwivedi, I.P. Tripathi and M. Suresh Kumar, Assessment of Soil and Ground water Quality in Rewa District of Vndhya Plateau (India). Journal Environment Sciences and Engs., 5(1), 5154 (2013).

[15] S. Sumithra, C. Ankalaiah, D Rao.and, R.T. Yamuna, A Case Study on Physic-chemical Characteristics of Soil Around Industrial and Agricultural Area of Yerraguntla, Kadapa District, A.P, India. Int. J. Geo. Earth and Environ. Sci., 3(2), 28-34 (2013).

[16] P.K. Govil, J.E. Sorlie, N.N. Murthy, D. Sujatha, D. Reddy G.L.N., Rodolph-lund kim, Krishna, A.K. and K. Rama Mohan, Soil Contamination of Heavy Metals in the Katedan Industrial Development Area, Hyderabad, India; Journal of Environment Assess., 140, 313-323 (2008).

[17] N.S. Sonawane, C.P. Sawani, R.V. Patil, Soil Quality Assessment and Heavy Metal Contamination in Agricultural Soil in and around Toranmal (Triable Region) of Maharashta, Applied Science Research, 5 (2), 294-298 (2013).

Citation: A. Prasad Dwived, "Assessment of Physico-chemical Characteristics of Soil collected from Various Locations of Chitrakoot Region, District Satna, Madhya Pradesh", International Journal of Advanced Research in Chemical Science (IJARCS), vol. 4, no. 4, pp. 40-45, 2017. http://dx.doi.org/10. 20431/2349-0403.040400

Copyright: () 2017 Authors. This is an open-access article distributed under the terms of the Creative Commons Attribution License, which permits unrestricted use, distribution, and reproduction in any medium, provided the original author and source are credited. 